\title{
PERKEMBANGAN PRODUKTIVITAS, LUAS LAHAN, HARGA DOMESTIK, PERMINTAAN DAN EKSPOR BIJI KAKAO INDONESIA PERIODE 1990-2013
}

\author{
Henoch Kindangen $^{*}$, , Sri Hartoyo ${ }^{* *}$, dan Lukman M. Baga ${ }^{* *}$ \\ *) Sekolah Bisnis, Institut Pertanian Bogor \\ Jl. Raya Pajajaran, Bogor 16151 \\ **) Departemen Ilmu Ekonomi, Fakultas Ekonomi dan Manajemen, Institut Pertanian Bogor \\ Jl. Agatis Kampus IPB Darmaga, Bogor 16680 \\ ${ }^{* * *}$ Departemen Agribisnis, Fakultas Ekonomi dan Manajemen, Institut Pertanian Bogor \\ Jl. Kamper Wing 2 Level 5, Kampus IPB Darmaga Bogor 16680
}

\begin{abstract}
Acreage development, production, productivity, and Indonesian cocoa exports cannot be separated from the influence of various cocoa policies applied by the Indonesian government and the international cocoa institution that is ICCO. The objective of this study was to analyze the factors that influence the behavior of the economy, including productivity, demand, export, and cocoa prices, and impact of domestic policy for the behavior of Indonesian cocoa economy. The analysis method used for the economy behavior was the simultaneous equation model with 2SLS approach (Two Stage Least Square). The analysis showed domestic production is influenced by cocoa price, fertilizer price, labor costs, and technology. Cocoa demand is influenced by the amount of domestic prices of processed cocoa. Cocoa exports is affected by the production, world prices, exchange rates, exports of cocoa from the previous year, and domestic demand for cocoa whereas domestic prices are influenced by world prices, domestic supply, and domestic prices of the previous year
\end{abstract}

Keywords: cocoa, 2SLS, behavior of the economy, demand, export

\begin{abstract}
ABSTRAK
Perkembangan luas areal, produksi, produktivitas,dan ekspor kakao Indonesia tidak lepas dari pengaruh berbagai kebijakan kakao yang diterapkan oleh pemerintah Indonesia dan lembaga kakao dunia, yaitu ICCO. Tujuan dari penelitian ini untuk menganalisis faktor-faktor yang memengaruhi perilaku ekonomi, termasuk produktivitas, permintaan, ekspor, harga kakao dan dampak kebijakan domestik untuk perilaku ekonomi kakao Indonesia. Analisis metode perilaku ekonomi yang digunakan adalah model persamaan simultan dengan pendekatan 2SLS (Two Stage Least Square). Hasil analisis menunjukkan produksi dipengaruhi oleh harga domestik kakao, harga pupuk, biaya tenaga kerja, teknologi. Permintaan kakao dipengaruhi oleh jumlah harga domestik olahan kakao. ekspor kakao dipengaruhi oleh produksi, harga dunia, nilai tukar, ekspor kakao dari tahun sebelumnya, permintaan domestik untuk kakao. harga domestik dipengaruhi oleh harga dunia, pasokan dalam negeri, harga domestik dari tahun sebelumnya.
\end{abstract}

Kata kunci: kakao, 2SLS, perilaku ekonomi, permintaan, ekspor

\footnotetext{
${ }^{1}$ Alamat Korespondensi:

Email: kindangen@live.com
}

\section{PENDAHULUAN}

Kakao (Theobrema cacao L.) adalah salah satu komoditas unggulan subsektor perkebunan. Komoditas kakao secara konsisten berperan sebagai sumber devisa negara yang memberikan kontribusi yang sangat penting dalam struktur perekonomian Indonesia (Arsyad et al. 2011). Komoditas kakao juga menjadi penyedia lapangan pekerjaan karena mampu menyerap tenaga kerja yang cukup besar. Selain itu kakao juga berperan dalam mendorong pengembangan wilayah dan pengembangan agroindustri (Rifin et al. 2007). Dari sisi luas areal, kakao menempati luar areal keempat terbesar untuk sub sektor perkebunan setelah kelapa sawit, kelapa, dan karet. Sebaliknya, dari sisi ekonomi kakao memberikan sumbangan devisa kelima terbesar 
setelah kelapa sawit dan karet (Hasibuan et al. 2012a). Meskipun Komoditas unggulan, secara umum usaha tani kakao rakyat masih memiliki kekurangan di berbagai aspek, mulai dari aspek budidaya pemeliharaan, panen/ pasca panen, pengolahan hingga pemasaran (Iqbal dan Dalimi, 2006). Hal ini dikarenakan untuk memperoleh biji kakao terfermentasi sempurna terdapat syarat dan perlakuan tertentu yang perlu dikatahui petani (Hasan dan Roswita, 2013).

Ditinjau dari produksinya, selama kurun waktu 1990 2013 produksi kakao Indonesia juga berfluktuasi dan cenderung meningkat. Rata-rata produksi kakao Indonesia mengalami peningkatan sebesar 15,89\% per tahun, produksi kakao terbesar dicapai tahun 2013 sebesar 918,96 ribu ton. Kakao merupakan salah satu andalan ekspor Indonesia, dimana Indonesia menempati urutan ketiga sebagai negara pengekspor kakao terbesar di dunia setelah Pantai Gading dan Ghana.

Ekspor kakao dalam bentuk biji kakao mengalami perkembangan dalam bentuk volume maupun penerimaan devisa. Hal ini dapat dilihat dari devisa yang dihasilkan mengalami peningkatan dari tahun ke tahun, yaitu pada tahun 1990 volume ekspor mencapai sekitar 119.000 ton. Pada tahun 1996, volume ekspor bahkan mencapai 322.000 ton dengan dan pada tahun 1999 total ekspor kakao mencapai 419.000 ton. Sudaryanto dan Hadi (2000) berpendapat bahwa upaya liberalisasi perdagangan bergulir dengan tujuan untuk meningkatkan efisiensi usaha, suplai, konsumsi, perdagangan (ekspor dan impor) dan kesejahteraan ekonomi masyarakat di seluruh dunia.

Perkembangan luas areal, produksi, produktivitas,dan ekspor kakao Indonesia tidak lepas dari pengaruh berbagai kebijakan kakao yang diterapkan oleh pemerintah Indonesia dan lembaga kakao dunia, yaitu International Cocoa Organization (ICCO) Puspita et al. (2015). Kebijakan-kebijakan yang langsung berhubungan dengan kakao berupa standar mutu, pajak nilai tambah dan perluasan areal tanam, sedangkan yang berhubungan tidak langsung adalah kebijakan upah tenaga kerja, tingkat suku bunga, subsidi pupuk dan depresiasi dan apresiasi nilai tukar. Selain itu, dengan posisi rebut tawar Indonesia yang lemah, maka perubahan-perubahan ekspor negara pesaing dan total ekspor dunia akan memengaruhi perkembangan luas areal, produksi, produktivitas, serta perkembangan ekspor kakao di Indonesia. Oleh karena itu, pertanyaannya adalah seberapa besar dampak kebijakan ekonomi yang berkaitan dengan perkembangan kakao, seperti luas areal, produksi, produktivitas, serta perkembangan ekspor kakao di Indonesia.

Kakao sebagai penghasil devisa nonmigas Indonesia, dewasa ini menempati urutan lima terbesar setelah karet, sawit, kopi dan teh. Peranan kakao dalam perekonomian Indonesia mempunyai arti penting dalam aspek sosial ekonomi, sebab selain merupakan sumber devisa negara juga penyedia lapangan kerja yang besar bagi penduduk serta sebagai sumber penghasilan bagi para petani terutama bagi mereka yang tinggal di daerah-daerah yang merupakan sentra produksi kakao itu sendiri, selain berfungsi dalam menyangga kelestarian produktivitas sumber daya alam.

Sehubungan dengan keadaan pasar biji kakao Indonesia, kaitannya untuk meningkatkan peluang dan pangsa ekspor biji kakao Indonesia sebagai salah satu komoditas perdagangan internasional, maka keadaan pasar kakao internasional maupun domestik akan turut berpengaruh terhadap perkembangan biji kakao Indonesia. Untuk itu perlu dikaji secara lebih mendalam faktor-faktor yang berpengaruh terhadap perkembangan biji kakao Indonesia, baik di pasar domestik maupun di pasar internasional.

Penelitian ini dilakukan dengan tujuan menduga model ekonometrika komoditas kakao baik dalam produktivitas, luas lahan, harga kakao dalam negeri, permintaan kakao dalam negeri, ekspor kakao tersebut. Selanjutnya, menganalisis faktor- faktor yang memengaruhi harga domestik, produktivitas, export, luas lahan, permintaan biji kakao.

\section{METODE PENELITIAN}

Data yang digunakan dalam penelitian ini adalah data sekunder, berupa data time series pada periode tahun 1990 hingga 2013 bersumber dari instansi terkait di lingkup Kementerian Pertanian dan instansi di luar Kementerian Pertanian, seperti Badan Pusat Statistik (BPS), ICCO selengkapnya pada Tabel 1. 
Tabel 1. Jenis dan sumber data

\begin{tabular}{ll}
\hline \multicolumn{1}{c}{ Variabel } & \multicolumn{1}{c}{ Sumber } \\
\hline Harga Domestik Kakao & Kementan \\
Luas Lahan & Kementan \\
Upah Buruh & BPS \\
Kurs & BPS \\
Harga Internasional Kakao & World Bank \\
Permintaan Kakao domestik & Kementan \\
Export kakao domestik & ICCO \\
Harga Pupuk & Kementan \\
\hline
\end{tabular}

Identifikasi model struktural yang dilakukan dalam penelitian ini adalah berdasarkan order condition model sedangkan variabel perilaku ekonomi kakao dalam penelitian ini adalah over identified. Oleh karena itu, analisis perilaku kakao dilakukanpendekatan simultan menggunakan metode 2 SLS (two stage least squares). Spesifikasi model persamaannya adalah sebagai berikut:

$$
\begin{aligned}
\mathrm{PKV}= & \alpha_{0}+\alpha_{1} \mathrm{PD}_{\mathrm{t}}+\alpha_{2} \mathrm{TE}_{\mathrm{t}}+\alpha_{3} \mathrm{UB}_{\mathrm{t}}+\alpha_{4} \mathrm{HP}_{\mathrm{t}}+ \\
& \alpha_{5} \mathrm{PKV}_{\mathrm{t}-1}+\mathrm{E}_{1} \\
\mathrm{LL}= & \beta_{0}+\beta_{1} \mathrm{PDt}+\beta_{2} \mathrm{UB}_{\mathrm{t}}+\beta_{3} \mathrm{LL}_{\mathrm{t}-1}+\mathrm{E}_{2} \\
\mathrm{PD}= & \gamma_{0}+\gamma_{1} \mathrm{Hi}_{\mathrm{t}}+\gamma_{2} \mathrm{KURS}_{\mathrm{t}}+\gamma_{3} \mathrm{DDK}_{\mathrm{t}}+ \\
& \gamma_{3} \mathrm{PKD}_{\mathrm{t}-1}+\mathrm{E}_{3} \\
\mathrm{DDK}= & \eta_{0}+\eta_{1} \mathrm{PD}_{\mathrm{t}}+\eta_{2} \mathrm{TE}_{\mathrm{t}}+\eta_{3} \mathrm{DDK}_{\mathrm{t}-1}+\mathrm{E} 4 \\
\mathrm{EXPD}= & \theta_{0}+\theta_{1} \mathrm{HI}_{\mathrm{t}}+\theta_{2} \mathrm{KURS}_{\mathrm{t}}+\theta_{3} \mathrm{EXPD}_{\mathrm{t}-1}+\mathrm{E}_{5}
\end{aligned}
$$

Keterangan:

PKV : Produktivitas biji kakao (ton/ha)

LL : Luas lahan tanaman kakao (ha)

PD : Harga domestik (Rp)

TE : Teknologi/Trend

UB : Upah Buruh (Rp)

HP : Harga Pupuk (Rp)

PD : Harga Domestik (Rp)

KURS : Kurs Rp Terhadap US dollar

DDK : Permintaan Kakao Domestik

HI : Harga Internasional (USD)

PKD : Produksi Kakao Domestik (ton)

EXPD : Export Kakao Domestik (ton)

$\mathrm{PKV}_{\mathrm{t}-1}$ : Peubah Kala dari PKV

$\mathrm{LL}_{\mathrm{t}-1} \quad$ : Peubah Kala dari LL

$\mathrm{PD}_{\mathrm{t}-1} \quad$ : Peubah Kala dari PD

DDK $_{t-1}$ : Peubah Kala dari DKK

EXPD $_{t-1}:$ Peubah Kala dari EXPD

E : Peubah Pengganggu
Produksi merupakan kegiatan suata barang dengan menggunakan faktor-faktor produksi. Luas Lahan merupakan salah faktor produksi. indonesia sejak tahun 1990-2013 terus mengalami peningakatan luas lahan, jika luas lahan meningkat maka biji kakao yang dihasilkan juga akan meningkat penulis mengharpkan adanya hubungan positif begitu juga sebaliknya

Kebijakan teknologi harus bertujuan menghasilkan keuntungan-keuntungan untuk menunjang produksi yang pada dasarnya mempertemukan dua aspek, yaitu penggalakan investasi yang memegang pemakaian teknologi baru, dan memaksimalkan penyerapan tenaga kerja, untuk diharapkan adanya hubungan positif antara produksi dan teknologi.

Harga kakao domestik mengikuti harga kakao internasional di bursa New York. Harga biji kering kakao domestik bergerak mengikuti fluktuasi harga kakao dunia walaupun arahnya tidak persis sama karena pengaruh nilai tukar rupiah terhadap dolar Amerika (Departemen Perindustrian dan Perdagangan, 2007). Peningkatan nilai ekspor kakao mungkin dilakukan karena harga dunia cenderung naik. Sehingga kesempatan untuk memetik keuntungan dari kenaikan harga atau kurangnya pasokan kakao dari negara lain seharusnya dapat dimanfaatkan secara maksimal. Namun, karena berbagai kendala klasik seperti rendahnya kualitas, serangan hama, atau penyempitan lahan, kesempatan ini tidak dimanfaatkan dengan baik (Departemen Perindustrian dan Perdagangan, 2007).

Indonesia merupakan negara pengekspor kakao yang masuk kedalam ICCO, indonesia terus melakukan penawaran ekspor kokoa dengan menggunakan kurs dollar, karena harga domestik menguikuti fluktuasi harga internasional jadi penulis mengharapkan ketika rupiah terapresiasi terhadap dollar maka harga domestik akan turun.

Model ekonometrika menggambarkan hubungan masing-masing peubah penjelas (explanatory variables) terhadap peubah endogen (dependent variabel), khususnya manyakut tanda dan besar koefien regresi yang diprediksi secara aprori dan teori teori ekonomi. Agar tercapai tujuaan penelitan yang telah ditentukan maka model disepsifikasi dalam bentuk persamaan simultan yang terdiri lima persamaan. Kerangka pemikiran penelitian selengkapanya pada Gambar 1. 


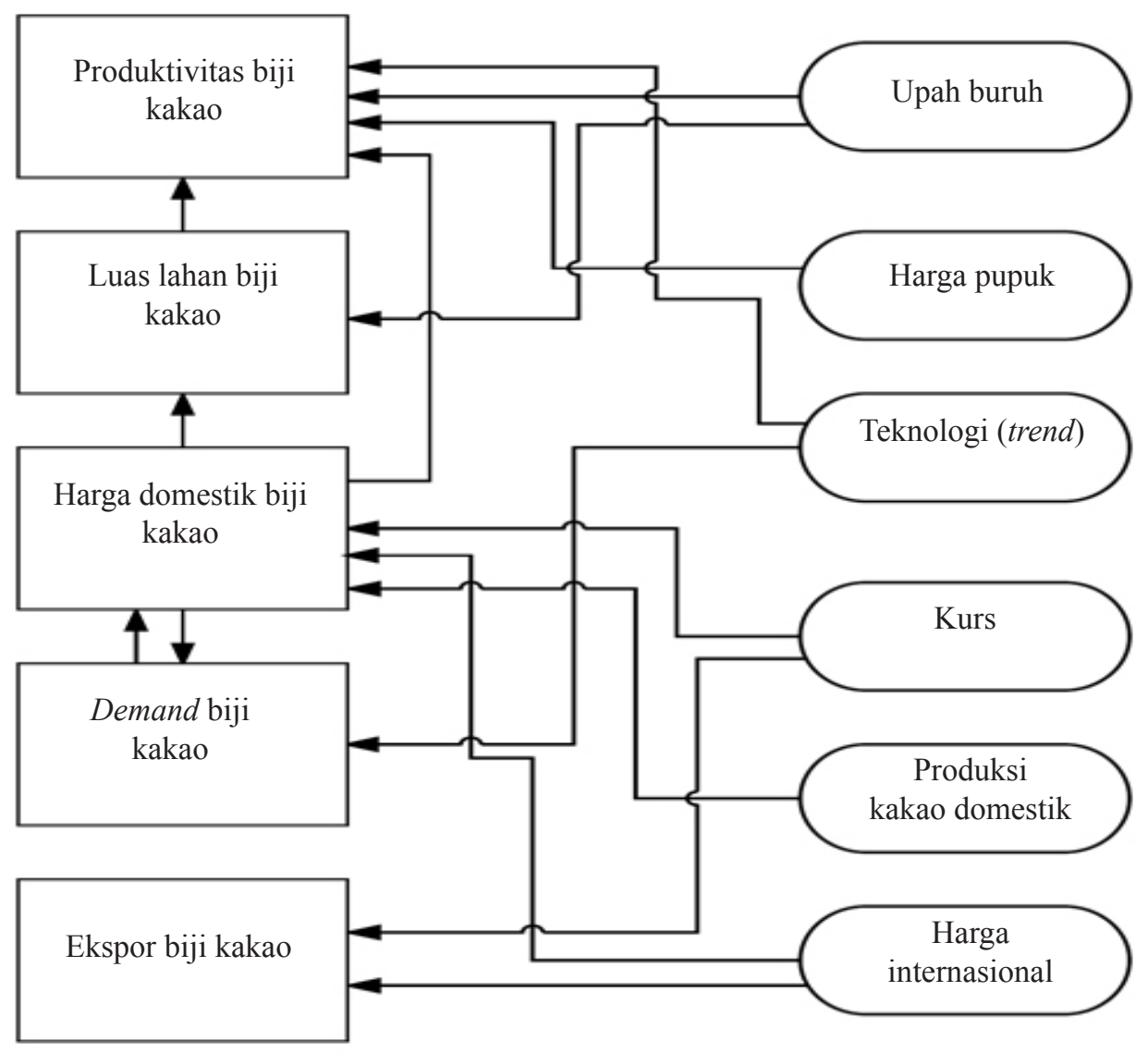

Gambar 1. Kerangka pemikiran penelitian

\section{Hipotesis Penelitian}

Terdapat lima hipotesis yang diajukan dalam penelitian ini, sebagai berikut:

- Harga domestik dan teknologi berpengaruh positif terhadap produktivitas biji kakao, sedangkan upah buruh dan harga pupuk berpengaruh negatif.

- Luas lahan dipengaruhi positif oleh harga domsetik sendagkan upah buruh berpengaruh negatif.

- Kurs, demand kakao, harga internasional memengaruhi harga domestik secara positif, sedangkan produksi kakao domestik berpengaruh negatif.

- Harga domestik berpengaruh secara negatif terhadap demand biji kakao, sedangkan trend waktu mepengaruhi secara positif

- Harga internasional dan kurs berpengaruh positif terhadap ekspor biji kakao indonesia

Sebelum melakukan alternatif simulasi kebijakan, terlebih dahulu dilakukan validasi model untuk melihat apakah nilai dugaan sesuai dengan nilai aktual masingmasing peubah endogen. Kriteria yang digunakan dalam validasi model adalah Root Mean Square Percentage
Error (RMSPE) dan Theil's Inequality Coefficient (U-Theil). Model kakao Indonesia dalam penelitian ini diuji dengan suatu simulasi yang dilakukan dengan beberapa skenario kebijakan untuk periode pengamatan tahun 1990-2013. Validasi model diperlukan untuk mengetahul kualitas model dalam menduga perilaku data aktual yang digunakan di dalam model. Validasi statistik yang diutamakan dalam penelitian ini adalah RMSPE untuk mengukur seberapa dekat nilai masingmasing peubah endogen hasil pendugaan mengikuti nilai data aktualnya selama periode pengamatan atau seberapa jauh penyimpangannya dalam ukuran persentase.

Selain itu, digunakan koefisien U-Theil untuk mengevaluasi kehandalan model untuk digtmakan dalam analisis simulasi kebijakan. Suatu pendugaan model dikatakan baik apabila nilai RMSE (Root Mean Square Error), RMSPE, dan U-Theil semakin kecil dengan nilal U (Thells Inequality Coefficient) berkisar antara 0 dan 1 , jika $U$ sama dengan 0 maka pendugaan model adalah sempuma. Sebaliknya, bila U sama dengan 1 maka pendugaan model sangat buruk. 


\section{HASIL}

Model persamaan yang dibangun adalah model linear persamaan simultan, yang diduga dengan metoda pangkat dua terkecil dua tahap atau 2 SLS. Hasil respesifikasi model diperoleh hasil pendugaan yang cukup baik. Hal ini ditunjukkan oleh nilai statistik F antara 6,21 hingga 171,86 dan nilai probability-F kurang dari 0,01 . Artinya, variasi dari peubah endogen secara nyata dapat dijelaskan oleh masing-masing peubah eksogen. Nilai koefisien determinasi $\left(\mathrm{R}^{2}\right)$ berkisar antara 0,73769 hingga 0,9746. Besaran $\mathrm{R}^{2}$ tersebut menjelaskan bahwa keragaman peubah endogen dapat dijelaskan oleh peubah eksogen secara bersama-sama. Dari 5 persamaan perilaku diperoleh nilai $\mathrm{R}^{2}$ yang cukup tinggi atau sebagian besar diatas $90 \%$. Artinya, model yang dibangun adalah cukup baik dimana $90 \%$ keragaman peubah endogen dapat dijelaskan secara bersama-sama oleh peubah eksogen, hasil dugaan (estimasi) parameter disajikan pada uraian berikut:

\section{Produktivitas Biji Kakao}

Produktivitas biji kakao Indonesia berhubungan positif dengan harga domestik biji kakao, dan teknologi serta produktivitas biji kakao tahun sebelumya (lag). Sedangkan upah buruh dan harga pupuk berhubungan negatif dengan produktivitas biji kakao. Hasil pendugaan parameter dinyatakan pada Tabel 2 .

Harga domestik memiliki pengaruh yang positif, jika harga domestic naik 1\% maka produktivitas biji kakao akan meningkat sebesar $0,153 \%$ pada jamgka pendek dan meningkat sebesar $0,158 \%$ pada jangka panjang peubah harga secara umum bersifa inelastis dalam komoditas perkebunan (Dradjat, 2003). Peubah teknologi memiliki pengaruh positif terhadap produktivitas biji kakao (Tumanggor, 2009)

Upah buruh dan harga pupuk memiliki pengaruh negatif terhadap biji kakao Indonesia (Drajat, 2003). Jika upah buruh turun 10\% maka produktivitas biji kakao akan menigkat sebesar $8 \%$ di jangka panjang dan jangka pendek. Namun, jika harga pupuk turun sebesar 1\% maka produktivitas biji kakao akan naik $0,56 \%$ pada jangka pendek dan $0,58 \%$ pada jangka panjang. Seluruh peubah memliki arah atau pengaruh yang sesuai dengan harapan penulis.

\section{Luas lahan Biji Kakao}

Luas lahan biji kakao atau arean tanam produktif biji kakao dipengaruhi oleh upah buruh sektor perkebunan dan harga domestik biji kakao. Hasil pendugaan disajikan pada Tabel 3.

Luas lahan biji kakao dipengaruhi oleh harga domestik dengan tanda parameter positif dan sesuai dengan hipotesa penelitian. Hal ini bermakna peubah harga merupakan singal pasar yang memengaruhi petani untuk meningkatkan area tanam produktif, dan selanjutnya akan meningkatkan produksi biji kakao. Hal tersebut juga didukung oleh fakta empiris dimana pertumbuhan areal kelapa sawit domestik yang terus meningkat dari tahun ke tahun dari 37,08 ribu ha pada tahun 1980 menjadi 1,74 juta ha pada tahun 2013. Ratarata peningkatan luas areal kakao mencapai 13,29\% per tahun. Peubah harga domestik memiliki parameter 24.783, jika harga kakao naik $1 \%$ maka luar areal tanam akan meningkat $0,0256 \%$ pada jangka pendek dan naik $0,149 \%$ pada jangka panjang.

Upah buruh sektor perkebunan memiliki pengaruh negatif terhadap luas lahan tanam biji kakao, jika upuh buruh turun $1 \%$ maka luas lahan akan meningkat sebsesar 0,086\% di jangka panjang dan naik sebesar 0,49 di jangka panjang. Hasil tersebut sesuai dengan hipotesis penelitian.

Tabel 2. Produktivitas biji kakao

\begin{tabular}{|c|c|c|c|c|}
\hline Variabel & $\begin{array}{c}\text { Parameter } \\
\text { Estimate }\end{array}$ & Prob $\mathrm{T}$ & SR & LR \\
\hline Intercept & 0,347489 & 0,0049 & & \\
\hline PD & 0,000010 & 0,5203 & 0,153 & 0,158 \\
\hline TE & 0,047870 & 0,0077 & 1,108 & 1,143 \\
\hline UB & $-0,00101$ & 0,0079 & $-0,810$ & $-0,836$ \\
\hline HP & $-0,00007$ & 0,4962 & $-0,056$ & $-0,058$ \\
\hline LPKV & 0,031012 & 0,9101 & & \\
\hline \multicolumn{2}{|c|}{ R-Square 0,73769} & \multicolumn{3}{|c|}{ Durbin-Watson 1,909536} \\
\hline
\end{tabular}

Tabel 3. Luas lahan biji kakao

\begin{tabular}{|c|c|c|c|c|}
\hline Variabel & $\begin{array}{c}\text { Parameter } \\
\text { Estimate }\end{array}$ & Prob $\mathrm{T}$ & SR & LR \\
\hline Intercept & 102534,7 & 0,2488 & & \\
\hline PD & 24,78309 & 0,0741 & 0,026 & 0,149 \\
\hline UB & $-197,140$ & 0,5533 & $-0,086$ & $-0,497$ \\
\hline LLL & 0,826502 & 0,0008 & & \\
\hline \multicolumn{2}{|c|}{ R-Square 0,98487} & \multicolumn{3}{|c|}{ Durbin-Watson 1,555987} \\
\hline
\end{tabular}




\section{Harga Biji Kakao Domestik}

Harga biji kakao domestik di pengaruhi positif peubah harga internasional, kurs rupiah terhadap dollar dan permintan kakao domestik, sedangkan produksi kakao domestik atau sebagai proxy dari supply memiliki pengaruh negatif (Tabel 4).

Harga biji kakao domestik dipengaruhi oleh harga internasional jika harga internasional naik 1\% maka harga biji kakao domestik akan naik sebesar 0,155\% pada jangka pendek dan naik sebesar 3,782\% pengaruh harga internasional lebih responsif terlihat pada jangka panjang. Kurs rupiah terhadap dollar memiliki pengaruh positif terhadap harga biji kakao domestik. Jika rupiah menguat 1.000 rupiah terhadap dollar maka harga produksi kakao meningkat sebesar 0,483 rupiah per kilogram. Pada jangka pendek pengaruh tersebut tidak responsif, sedangkan pada jangka panjang pengaruh kurs rupiah terhadap dollar responsif. Damanik (2010) pasar dan harga kakao domestik mengikuti harga internasional terutama harga di bursa diterbitkan oleh Balai Besar Industri Hasil Perkebunan New York karena sebagian besar ekspor kakao Indonesia ditujukan ke Amerika Serikat.

Demand kakao domestik memiliki pengaruh positif jika permintaan naik 1\% maka harga domestik kakao akan meningkat sebesar $0,431 \%$ pada jangka pendek dan $10,480 \%$ pada jangka panajang. Terlihat demand lebih responsif pada jangka panajang terhadap harga kakao domestik. Hal tersbut juga sesuai dengan hukum permintaan.

Produksi kakao domestik memiliki tanda perameter negatif jika produksi kakao indonesia turun $1 \%$ maka harga kakao domestik akan naik sebesar 0,659 pada jangka pendek dan $16,017 \%$ pada jangka panjang. Hasil tersebut menunjukan pengaruh produksi terlihat responsif pada jangka panjang. Menurut Conforti (2004) ada enam faktor yang memengaruhi transmisi harga diantaranya adalah biaya transportasi dan transaksi, kekuatan pasar, increasing return of scale pada produksi, produk yang homogen dan differensiasi, nilai tukar, kebijakan dalam negeri suatu negara. Irawan (2007) juga menjelaskan proses transmisi harga yang tidak sempurna dan bersifat asimetris terjadi pada komoditas pertanian.

\section{Permintaan Biji Kakao Domestik}

Permintaan biji kakao domestik dipengaruhi oleh harga dalam negeri dan peubah TE, yaitu trend waktu. Harga domestik biji kakao memiliki nilai pengaruh negatif, yaitu jika harga kakao domestik turun 1\% maka permintaan kakao akan meningkat $0,173 \%$ pada jangka pendek dan naik sebesar 0,665 pada jangka panjang, peubah trend juga memiliki pengaruh positif (Tabel 5). Hasil tersebut seusai dengan hipotesa peneliti. Permintaan dapat diekspresikan dalam bentuk kurva yang menunjukkan hubungan negatifantara jumlah barang yang diminta pada berbagai tingkat harga. Seperti halnya penawaran, permintaan juga dapat diekspresikan dalam bentuk fungsi matematis, dimana permintaan merupakan fungsi dari berbagai faktor seperti; permintaan tahun sebelumnya, harga barang tersebut, harga barang lain, pendapatan perkapita, jumlah penduduk, dan lain-lain. Permintaan tahun sebelumnya memengaruhi permintaan tahun ini sebagai akibat dari pembentukan kebisaaan atau habits formation (Wohlgenant dan Hahn, 1982)

\section{Ekspor Biji Kakao Indonesia}

Ekspor biji kakao indonesia di pengaruhi oleh harga internasional kakao dan kurs rupiah terhadap dollar, harga internasional memilliki pengaruh positif terhadap ekspor biji kakao Indonesia jika harga internasional naik $1 \%$ maka ekspor biji kakao akan meningkar $0,133 \%$ pada jangka pendek dan $0,460 \%$ pada jangka panjang, hasil pendugaan sesuai dengan harapan penulis (Tabel $6)$.

Tabel 4. Harga biji kakao domestik

\begin{tabular}{|c|c|c|c|c|}
\hline Variabel & $\begin{array}{c}\text { Parameter } \\
\text { Estimate }\end{array}$ & Prob. $\mathrm{T}$ & SR & LR \\
\hline Intercept & $-2650,57$ & 0,4265 & & \\
\hline $\mathrm{HI}$ & 0,402126 & 0,7985 & 0,155 & 3,782 \\
\hline KURS & 0,483894 & 0,0232 & 0,408 & 9,915 \\
\hline DDK & 0,003944 & 0,1429 & 0,431 & 10,480 \\
\hline PKD & $-5,24607$ & 0,0355 & $-0,659$ & $-16,017$ \\
\hline LPD & 0,9878 & 0,0001 & & \\
\hline \multicolumn{2}{|c|}{ R-Square 0,97688} & \multicolumn{3}{|c|}{ Durbin-Watson 1,576726} \\
\hline
\end{tabular}


Tabel 5. Harga biji kakao domestik

\begin{tabular}{lcccc}
\hline \multicolumn{1}{c}{ Variabel } & $\begin{array}{c}\text { Parameter } \\
\text { Estimate }\end{array}$ & Prob. T & SR & LR \\
\hline Intercept & 98059,78 & 0,1533 & & \\
PD & $-18,8906$ & 0,2515 & $-0,173$ & $-0,665$ \\
TE & 25625,96 & 0,2493 & 0,356 & 1,367 \\
LDDK & 0,739995 & 0,0012 & & \\
\hline
\end{tabular}

R-Square 0,93165

Durbin-Watson 1,922011

Tabel 6. Ekspor biji kakao Indonesia

\begin{tabular}{lcccc}
\hline \multicolumn{1}{c}{ Variabel } & $\begin{array}{c}\text { Parameter } \\
\text { Estimate }\end{array}$ & Prob. T & SR & LR \\
\hline Intercept & 97666,91 & 0,6500 & & \\
HI & 37,47168 & 0,7367 & 0,133 & 0,460 \\
Kurs & 35,01687 & 0,0241 & 0,270 & 0,937 \\
LEXPD & 0,711861 & 0,0001 & & \\
\hline \multicolumn{2}{c}{ R-Square } & 0,95247 & \multicolumn{2}{c}{ Durbin-Watson 2,15884 } \\
\hline
\end{tabular}

Nilai parameter dugaan nilai tukar IDR terhadap USD sebesar 0,0241, dimana kenaikan nilai tukar IDR terhadap USD sebesar 1000 IDR per USD, akanmenyebabkan ekspor kakao meningkat sebesar 2.241 ribu ton. Dalam jangka pendek dan jargka panjang, ekspor biji kakao Indonesia kurang responsif terhadap nilai tukar IDR terhadap USD. Nilai tukar IDR terhadap USD mempunyai peranan yang sangat penting dalam perdagangan kakao Indonesia. Melemahnya nilai tukar IDR terhadap USD akan menyebabkan tingginya harga jual kakao jika diekspor dibandingkan dengan harga kakao domestik, ekspor kakao Indonesia meningkatkan. Saefuddin (2000) meningkatnya nilai tukar USD terhadap IDR, temyata sangat menguntungkan bagi jenis komoditas ekspor yang menggunakan bahan lokal seperti kakao. Penggunaan nilai tukar dalam model gravity yang pertama kali melakukan adalah Bergstrand (1985). Berbagai penelitian selanjutnya yang mengganalisis aliran perdagangan dengan model gravity banyak memasukkan nilai tukar riil menjadi salah satu variabel sebagai pendekatan dari term of trade. Variabel nilai tukar diduga akan berpengaruh positif terhadap nilai ekspor Hasil estimasi penelitian Tenreyro (2007) terhadap beberapa negara menghasilkan kesimpulan bahwa nilai tukar tidak memiliki pengaruh signifikan terhadap ekspor. Ekananda (2004) menyimpulkan bahwa fluktuasi nilai tukar dan volatilitas nilai tukar rupiah memiliki elastisitas yang berbeda pada setiap nilai ekspor komoditas. Pengaruh ini dapat saja signifikan atau bahkan tidak signifikan sama sekali. Pengembangan kakao memang tidak terlepas dari perannya sebagai salah satu komoditas perkebunan yang menjadi fokus pengembangan untuk tujuan ekspor Anggita et al. (2015).

\section{Pencabutan Subsidi Harga Pupuk 20\%}

Sejak Pelita 1 pemerintah telah memberikan subsidi pupuk sehingga petani membeli pupuk lebih rendah dari harga ekonominya. Secara bertahap pengurangan subsidi oleh pementrintah akan menyebabkan petani membeli pada harga ekonomi. Berdasarkan kondisi ini maka dicoba skenario pencabutan subsidi pupuk, dimana harga pupuk meningkat $20 \%$

Subsidi yang dicabut akan memengaruhi produktivitas kakao sehingga produksi pun akan menurun sebesar $8,66 \%$. Produktivitas yang menurun akan diikuti penurunan jumlah permintaan kakao di pasar domestik sebesar 5,44\% dan disertai luas lahan kakao juga turun sebesar 2,4\%. Jumlah kakao yang diekspor akan berkurang sebesar 7,2\%. Kondisi demikian bukan tidak mungkin menjadikan komoditas kakao menjadi langka. Apabila ketersediaan kakao di pasaran langka, maka membuat harganya semakin mahal. Hal ini ditunjukkan dengan rata-rata laju peningkatan harga sebesar $2,63 \%$.

\section{Peningkatan Upah Buruh Sektor Perkebunan Naik $20 \%$}

Peningkatan upah sektor perkebunan sebesar 20\%. Pada kondisi sekarang ini, muncul permasalahan mengenai tingkat upah para buruh yang disebabkan upah yang berlaku sekarang rendah sehingga dijadikan alasan rendahnya produktivitas. Dengan demikian, penulis mencoba menaikan upah buruh perkebunan sebesar $20 \%$. Peningkatan harga upah buruh sektor pertanian akan menurunkan produktivitas dan luas lahan sebesar $6,7 \%$ dan $1,4 \%$, seiring produktivitas menurun harga kakao meningkat sebesar $4,77 \%$, ekspor biji kakao juga mengalami penurunan sebesar $11 \%$, permintaan turun sebesar 3,2\% (Tabel 7). 
Tabel 7. Skenario kebijakan harga pupuk dan upah buruh

\begin{tabular}{lcc}
\hline \multicolumn{1}{c}{ LABEL } & $\begin{array}{c}\text { Harga Pupuk } \\
\text { naik 20\% }\end{array}$ & $\begin{array}{c}\text { Upah Buruh } \\
\text { Naik 20\% }\end{array}$ \\
\hline $\begin{array}{l}\text { Produktivitas biji } \\
\text { kakao(Ton/Ha) }\end{array}$ & $-8,6$ & $-6,7$ \\
$\begin{array}{l}\text { Luas lahan tanaman kakao } \\
\text { (Ha) }\end{array}$ & $-2,4$ & $-1,4$ \\
$\begin{array}{l}\text { Harga domestik (Rp) } \\
\begin{array}{l}\text { Permintaan Kakao } \\
\text { domestik }\end{array}\end{array}$ & 2,6 & 4,7 \\
$\begin{array}{l}\text { Ekspor kakao domestik } \\
\text { (Ton) }\end{array}$ & $-5,4$ & $-3,2$ \\
\hline
\end{tabular}

\section{Implikasi Manajerial}

Kebijakan kenaikan harga pupuk dan kenaikan upah tenaga kerja berdampak negatif terhadap produktivitas dan demand. Oleh sebab itu, perlu adanya kebijakan lain yang mendorong kenaikan demand dan produktivitas kakao domestik yang berdampak ke penerimaan berupa perbaikan harga mutu kakao dan perbaikan mekanisme pasar yang dapat meningkatkan permintaan dan produktivitas biji kakao.

Untuk meningkatkan mutu kakao Indonesia yang berdampak ke daya saing kita terhadap negara lain, sebaiknya kebijakan difokuskan pada produksi kakao melalui perluasan luas areal kakao dan peningkatan produktivitas kakao. Untuk meningkatkan pendapatan petani maka perlu ditekankan kepada hasil panen yang bermutu baik dan kemudahan bagi petani untuk menjual atau masuk pasar perdagangan kakao. Dengan mengaktifkan para penyuluh petani untuk mensosialisikan pentingnya menghasilkan kakao yang bermutu seusai dengan standar mutu serta bimbingan dengan cara penanganan kakao yang sesuai dengan standar mutu.

Upaya peningkatan devisa dengan mempertimbangkan nilai tambah yang diterima dari kakao melalui pengembangan dalam bentuk kakao olahan, seperti tepung kakao, mentega kakao, coklat dan lain-lain, maka perlu dipertimbangkan suatu kebijakan yang dapat mengembangkan industri olahan kakao sehingga konsumsi olahan kakao domestik dapat dipenuhi tanpa harus mengimpor.

Pemerintah dapat menciptakan iklim usaha kakao yang kondusif, merupakan syarat untuk suatu aktivitas ekonomi dapat tumbuh dengan baik.
Kebijakan yang dapat di ambil pemerintah untuk menunjang pengembangan sektor perkebunan adalah pengembangan infrastuktur pertanian yang berkelanjutan. Kebijkan makro diwujudkan dalam nilai tukar yang stabil, inflasi yang terkendali.

\section{KESIMPULAN DAN SARAN}

\section{Kesimpulan}

Hhasil penelitian dan analisis data yang telah dilakukan, dapat disimpulkan bahwa seluruh hipotesa penelitian berpengaruh sesuai tujuan penelitian. Teknologi dan harga domestik berpengaruh positif terhadap produktivitas biji kakao, upah buruh dan harga pupuk berpengaruh negatif terhadap produktivitas biji kakao. Luas lahan yang dipengaruhi positif oleh harga domestik kakao dan negatif oleh upah buruh. Harga domestik biji kakao dipengaruhi positif oleh harga internasional, permintaan domestik, kurs rupiah terhadap dollar, dan supply memiliki pengaruh negatif terhadap harga domestik biji kakao. Permintaan kakao dipengaruhi negatif oleh harga domestik dan positif oleh trend waktu. Harga internasional dan kurs memilik pengaruh positif terhadap ekspor kakao Indonesia. Strategi dalam rangka mempertahankan dan meningkatkan mutu kakao indonesia yang berdampak ke daya saing kita terhadap negara lain, sebaiknya kebijakan difokuskan pada produksi kakao melalui perluasan luas areal kakao dan peningkatan produktivitas kakao.

\section{Saran}

Pengembangan studi mengenai komoditas kakao maka penelitian lanjutaan disarankan sebagai berikut: 1) membedakan hasil produksi dan produktivitas melalui satus usahanya, yaitu perkebunan swasta, rakyat, negara. 2) Biji kakao merupakan bahan baku industri olahan maka perlu kiranya dianalisis perilaku dari produk-produk output, seperti bubuk kakao, mentega kakao, pasta kakao dan kakao batangan. 3) Guna meningkatkan produksi dan harga kakao, perlu adanya peningkatan pengawasan terhadap kebijakan penerapan teknologi seperti Grateks dan Gernas Kakao. Dengan pengawasan yang sesuai program teknologi Grateks dan Gernas diharapkan produksi dan kualitas kakao meningkat sehingga juga dapat meningkatkan harga, permintaan dan ekspor. 4) Selain itu, diperlukan penelitian lebih lanjut terkait perilaku perekonomian kakao dengan menambahkan variabel konsumsi kakao, 
melihat perkembangan deman biji kakao atau demand hasil olahan kakao di inodenesia.

\section{DAFTAR PUSTAKA}

Anggita T, Anna F, Amzul R. 2015. Daya saing kakao indonesia di pasar internasional. Jurnal Manajemen dan Agribisnis 2(2): 150-162.

Arsyad M, Sinaga BM, Yusuf S. 2011. Analisis dampak kebijakan pajak ekspor dan subsidi harga pupuk terhadap produksi dan ekspor kakao Indonesia pasca putaran Uruguay. Jurnal Sosial Ekonomi Pertanian 8 (1): 63-71.

Bergstrand J H. 1985. The gravity equation in international trade: one microeconomic foundations and empirical evidence. The Review of conomics and Statistics 67(3):474-481. https://doi.org/10.2307/1925976.

Conforti P. 2004. Price transmission in selected agriculture markets. Commodity and Trade Policy Research Working Paper No.7 Roma.

Damanik 2010. Prospek dan strategi pengembangan perkebunan kakao berkelanjutan di Sumatera Barat. Jurnal Perspektif 9(2): $94-105$

Departemen Perindustrian dan Perdagangan. 2007. Membangun Daya Saing Industri Daerah dengan Pendekatan Kompetensi Inti Industri Daerah. Jakarta: Departemen Perindustrian.

Drajat B. 2003. Evaluasi dan prospek kinerja subsektor perkebunan pada era perdagangan bebas dunia [disertasi]. Bogor: Institut Pertanian Bogor.

Ekananda M. 2004. Analisis pengaruh volatilitas nilai tukar pada ekspor komoditas manufaktur di Indonesia penerapan estimasi dengan menggunakan distribusi lag poissons pada persamaan non linier seemingly unrelated regression. Buletin Ekonomi Moneter dan Perbankan Bank Indonesia 7(4): 197-235.

Hasan N, Roswita R. 2013. Peningkatan produktivitas dan mutu kakao melalui Diseminasi MultiChannel (Dmc) di Nagari Parit Malintang,
Kabupaten Padang Pariaman. Jurnal Teknologi Pertanian Universitas Mulawarman 8(2): 7582.

Hasibuan AM, Nurmalina R, Wahyudi A. 2012a. Analisis kinerja dan daya saing perdagangan biji kakao dan produk kakao olahan indonesia di Pasar Internasional. Buletin RISTRI 3(1): 5770.

Iqbal M, Dalimi A. 2006. Kebijakan pengembangan agribisnis kakao melalui primatani:kasus Kabupaten Luwu, Provinsi Sulawesi Selatan. Analisis Kebijakan Pertanian 4 (1): 39-53

Irawan B. 2007. Fluktuasi harga, transmisi harga dan margin pemasaran sayuran dan buah. Analisis Kebijakan Pertanian 5(4): 358-373.

Kementerian Pertanian. 2014. Outlook Komoditas Kakao. Jakarta: Pusat Data dan Sistem Informasi Pertanian Sekretariat Jenderal Kementerian Pertanian.

Puspita R, Hidayat K, Yulianto E. 2015. Pengaruh produksi kakao domestik, harga $\mathrm{k}$ a $\mathrm{k}$ a $\mathrm{o}$ internasional, dan nilai tukar terhadap ekpos kakao indonesia ke Amerika Serikat. Jurnal Administrasi Bisnis 27(1):1-8.

Rifin A, Nurdiyani F. 2007. Integrasi pasar kakao Indonesia. Jurnal Agribisnis dan Ekonomi Pertanian 1(2): 1-12.

Sudaryanto T, Susilowati SH. 1991. Perkembangan ekonomi kakao dunia dan implikasinya bagi Indonesia. Forum Penelitian Agro Ekonomi 9(1): 36-45.

Tenreyro S. 2007. On the trade impact of exchange rate volatility. Journal of Development Economics 82 (2): 485-508. https://doi.org/10.1016/j. jdeveco.2006.03.007.

Tumanggor DS. 2009. Analasis faktor-faktor yang memepengaruhi produksi coklat di Kabupaten Dairi [Tesis]. Medan: Universitas Sumatera.

Wohlgenant MK, Hahn WF. 1982. Dynamic adjustment inmonthly consumer demand formeats. American Journal of Agricultural Ekonomics (AJAE) 64 (3): 553-557.https://doi.org/10.2307/1240649. 